[Original]

\title{
PVN c-fos Expression, HPA Axis Response and Immune Cell Distribution during Restraint Stress
}

\author{
Zhengguo TAN, Shoji NAGATA \\ Department of Mental Health, Institute of Industrial and Ecological Sciences, University of Occupational \\ and Environmental Health, Japan. Yahatanishi-ku, Kitakyushu 807-8555, Japan
}

Abstract: It is well known that stress affects the central nervous system(CNS), neuroendocrinoimmune system and other peripheral organs such as the gastrointestinal tract. However, the process of adaptation or recovery after acute stress reactions in these systems or organs during prolonged stress has not yet been adequately investigated. To clarify the process of adaptation or recovery in these systems and organs after acute stress reactions, the time course of these responses during a single longduration restraint stress (RTS) was studied. The expression of $c-f o s$ in the hypothalamic paraventricular nucleus (PVN) region of the brain was induced and reached a peak at 0.5 hours for $c$-fos mRNA and 4 hours for $c$-fos protein(Fos), but disappeared at 2 hours for mRNA and 16 hours for Fos during continuous RTS. The activation of the hypothalamic-pituitary-adrenal(HPA)axis during stress resulted in rapid increases in the plasma levels of adrenocorticotropic hormone $(\mathrm{ACTH})$ and corticosterone (CORT). Whereas the increase in ACTH was transient, the rise in CORT was maintained throughout the duration of the stress. A rapid significant decrease after stress exposure and following a slow and complete or partial recovery were observed in a number of total white blood cells (WBC), lymphocytes (LYM), helper T cells (Th) and cytotoxic/suppressor T cells $(\mathrm{CTL} / \mathrm{Ts})$. A gastric ulcer was found in 1/6 and 6/6 rats at 8 hours and 16 hours RTS, respectively. These results suggest that adaptive changes may occur in $c$-fos expression in the PVN, ACTH release and immune response, but not for CORT release, following acute stress reaction during long-duration RTS. In addition, any associated organic damage, such as gastric ulceration, was also suggested to possibly be progressive according to the duration of RTS.

Key words:restraint stress(RTS), c-fos mRNA/protein, HPA axis, immune cell, gastric ulceration.

(Received 15 February 2002, accepted 17 April 2002)

\section{Introduction}

It is now well recognized that acute restraint stress (RTS) can induce neuronal activation in various brain regions, including the hypothalamic paraventricular nucleus (PVN), followed 
by the activation of the hypothalamic-pituitary-adrenal(HPA)axis, and changes in the immune functions $[1-4]$. The brain plays a primary role in conducting the stress response. The PVN with corticotropin releasing hormone ( $\mathrm{CRH}$ ) and arginine vasopressin (AVP) neurons appears to be essential for the regulation of the HPA axis as the center of stress neurocircuitary, in which stress-induced neuronal activation can be detected using $c$-fos mRNA and/ or $c$-fos protein (Fos) as a marker of neuronal activation $[5,6]$. As a result, $c$-fos mRNA and/or Fos induction in the PVN is an index of activation for neurosecretory neurons which are connected to the HPA axis [7]. The effect of the stress-induced activation of the HPA axis corresponds to the increase in the plasma adrenocorticotropic hormone $(\mathrm{ACTH})$ and corticosterone (CORT) levels $[2,8]$. The HPA axis is not only a potent bioenergetic regulator and a major anti-inflammatory actor, but is also a key junction for the neuroendocrinoimmune system [8]. It is known that the nervous, endocrine and immune systems combine to regulate the immune functions by additive or synergistic, agonistic and/or antagonistic means [9]. As a result, the stress-induced changes in various immune indexes, including the immune cell distribution and the weights of the immune organs etc., are multiple and complex.

There is little information regarding the time course of $c$-fos mRNA and Fos expression induced by acute long-duration stress in the brain. Senba and Chowdhury et al. $[1,6]$ demonstrated, respectively, adaptive changes in $c$-fos expression, which return to the baseline after a transient increase in $c$-fos mRNA at 2 hours and in Fos at 4 hours in many brain regions to acute immobilization stress (IMOS). Furthermore, Chowdhury [6] also reported that the PVN and locus coeruleus are relatively resistant to adaptation to acute IMOS in comparison to other brain regions. There is also little information on the time course of the immune response to acute long-duration RTS. Dhabhar et al. [10] demonstrated the changes in the time course of blood leukocyte distribution and corresponding CORT during a 2-hour RTS session, and observed a complete recovery in blood leukocyte distribution within 3 hours after the cessation of stress. Shimizu et al . [11] reported that RTS-induced apoptosis in the peripheral blood is more severe at 24 hours than at 12 hours. Several observations have indicated that various kinds of stress are closely related to acute upper gastrointestinal erosions and ulcerations [12].

The RTS or IMOS procedure has widely been used for the investigation of the pharmacological, physiological or pathologic phenomena as a popular tool [13]. In order to clarify the induction and adaptive change of the stress response in the central nervous system (CNS), HPA axis, immune system and other organs, we investigated the magnitude and time course of these responses from 0 to 16 hours using an acute long-duration RTS model. 


\section{Materials and Methods}

\section{Animals}

Wistar rats (male, 9 weeks, 290-340 g) (Seac Yoshitomi Ltd., Fukuoka, Japan) were used for the study. Rats, three per each cage, were housed in a light-controlled (light on 7:00 and off 19:00) room under a constant temperature $\left(23-25^{\circ} \mathrm{C}\right)$ and humidity with free access to food and water.

\section{Experiment procedures}

After a one-week acclimation to the environment, the experimental protocol was started at 9 weeks of age. The rats were divided randomly into two experimental groups. Rats in the stress group were subjected to a RTS by wrapping them in an iron net. Rats in the control group were left in their cages without food or water during the same time period, in order to avoid differences in food and water intake. In each experimental group the untreated rats were used as a normal control ( 0 hour $)$. The RTS was stopped at 9:00 according to the experimental schedule to avoid any influence of endocrine circadian rhythm (Fig. 1 ).

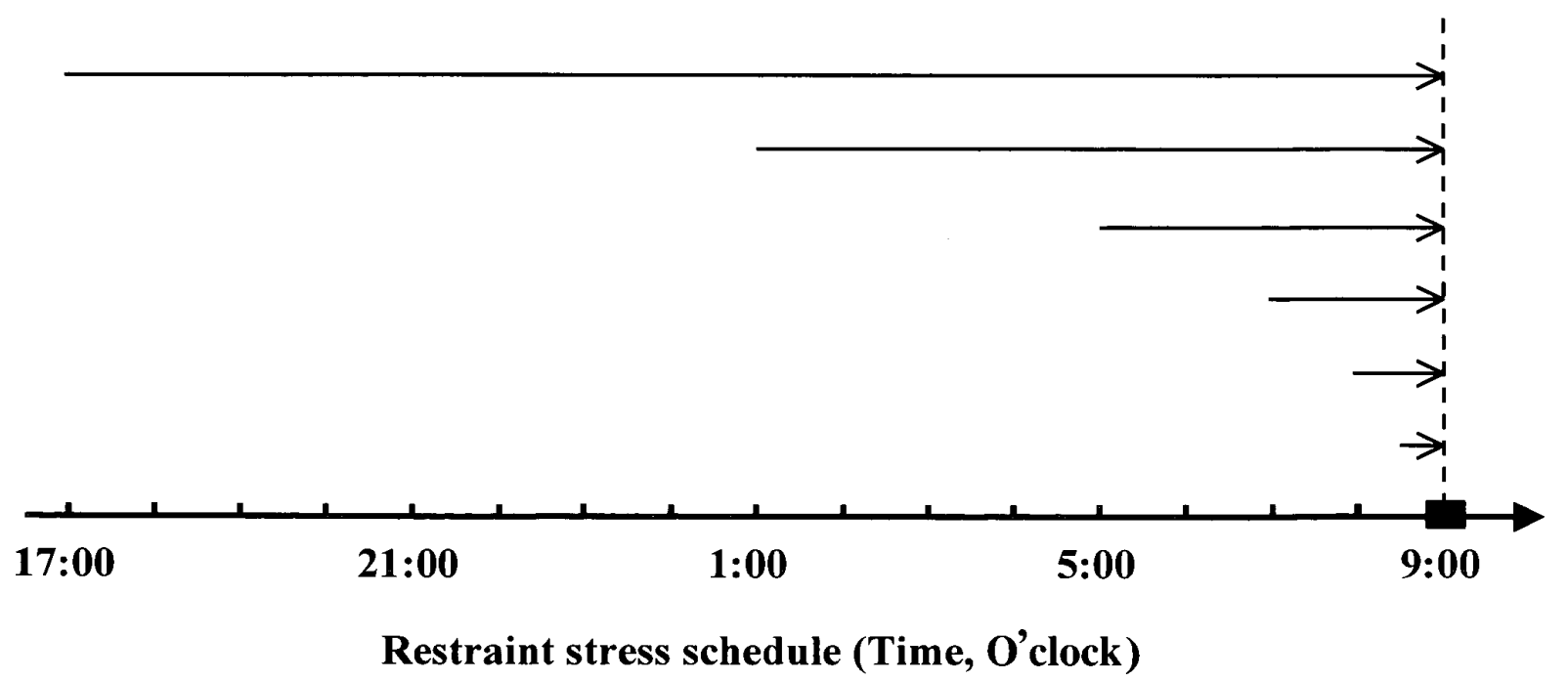

Fig. 1. Experimental schedule. The rats were continuously stressed for the periods of 0.5 (from 8:30 to 9:00), 1 (from 8:00 to 9:00), 2 (from 7:00 to 9:00), 4 (from 5:00 to 9:00), 8 (from 1:00 to 9:00) and 16 hours (from 17:00 of the previous day to 9:00) according to the experimental schedule to avoid any influence of endocrine circadian rhythm. After the treatment, the rats, to detect the expression of $c$-fos mRNA, were immediately decapitated at 9:00, and the rats to be examined for the expression of Fos and other parameters were immediately anesthetized and perfused at 9:00. 
Experiment 1. Animals with three rats per period were stressed for the periods of $0.5,1,2$, 4, 8 and 16 hours to detect the expression of $c$-fos mRNA. Immediately after the treatment, the rats were sacrificed by decapitation at 9:00. The brains were quickly removed, frozen on dry ice and stored at $-80^{\circ} \mathrm{C}$.

Experiment 2. Animals with six rats per period were stressed for the periods of 1, 2, 4, 8 and 16 hours to examine the expression of Fos and other parameters including endocrine and immune indices. After the treatment, the animals were immediately anesthetized by injecting them intraperitoneally with pentobarbital $(75 \mathrm{mg} / \mathrm{kg})$ at 9:00. After the animals were deeply anesthetized, the body weight (BW) was measured, and blood samples were collected by a cardiopuncture in heparinized tubes and immediately placed on a shaker to prevent clotting. The brain, the thymus, the adrenal gland and the stomach were quickly removed after the rats were perfused.

\section{Expression of c-fos}

In situ hybridization(ISH). Frozen $12 \mu \mathrm{m}$ transverse sections were cut using a cryostat and mounted onto gelatine/chrome alum-coated slides that were kept at $-80^{\circ} \mathrm{C}$ until use. The probe used was 3' -end ${ }^{35} \mathrm{~S}$-labeled deoxyoligonucleotides complementary to bases $138-$ 185 of the rat $c$-fos gene cording sequence: $5^{\circ}-\mathrm{CAG}$ CGG GAG GAT GAC GCC TCG TAG TCC GCG TTG AAA CCC GAG AAC AAC ATC - 3', and the specific activity of the ${ }^{35} \mathrm{~S}$-labeled probe was $0.5-1.0 \times 10^{6} \mathrm{cpm} / \mu 1$. The specificity of $c$-fos probe was confirmed by a previous study [14]. ISH procedures followed the report of Serino et al. [15]. Briefly, the sections were fixed in $4 \%$ formaldehyde, incubated in saline containing $0.25 \%$ acetic anhydride and $0.1 \mathrm{M}$ triethanolamine, dehydrated in ethanol solutions, and delipidated in chloroform. Hybridization was carried out overnight at $37^{\circ} \mathrm{C}$ in $45 \mu 1$ hybridization buffer containing $50 \%$ formamide and $4 \times \mathrm{SSC}(1 \times \mathrm{SSC}=150 \mathrm{mM} \mathrm{NaCl}$ and $15 \mathrm{mM}$ sodium citrate), $500 \mu \mathrm{g} / \mathrm{ml}$ sheared salmon sperm DNA (Sigma Chemical Co., St. Louis, MO, USA), $250 \mu \mathrm{g} / \mathrm{ml}$ baker's yeast total RNA(Boehringer Mannheim, Mannheim, Germany), $1 \times$ Denhardts' s solution (0.02\% Ficoll, $0.02 \%$ polyvinylpyrolidone and $0.02 \%$ bovine serum albumin) and $10 \%$ dextran sulfate $(500,000 \mathrm{MW}$, Sigma Chemical Co. $)$ under a Nescofilm (Bando Chemical IMD Ltd., Osaka, Japan) coverslip. The total count of radioactivity on a slide was adjusted to $1 \times 10^{6} \mathrm{cpm}$. After hybridization, sections were washed with $1 \times \mathrm{SSC}$ at $55^{\circ} \mathrm{C}$ and room temperature, respectively. Hybridization sections were apposed to autoradiography film (Hyperfilm, Amersham, Bucks, UK) for $10 \sim 14$ days. All sections obtained from independent experiments were simultaneously hybridized, washed, and exposed to minimize the variable effects of hybridization and wash stringency. The PVN was localized according to the atlas made by Swanson [16]. A quantitative image analysis was undertaken with a MCID Image Analysis System(Imaging Research Inc., Ontario, Canada). The mean optical density of autoradiographs was measured by comparing it with simultaneously exposed ${ }^{14} \mathrm{C}$ microscale samples (Amersham). The standard curve was 
fitted with the optical density of the ${ }^{14} \mathrm{C}$ microscale samples in the same film.

Immunohistochemistry. The rats were perfused transcardially with a perfusion of fixative containing $4 \%$ paraformaldehyde, $0.2 \%$ picric acid in $0.1 \mathrm{M}$ phosphate buffer $(\mathrm{pH} 7.4)$. The brains were removed and postfixed at $4{ }^{\circ} \mathrm{C}$ for 48 hours, and then were cryoprotected with $20 \%$ sucrose for 24 hours. The serial sections of $20 \mu \mathrm{m}$ were cut using a microtome. Standard immunohistochemical procedures followed the report of Ueta et al. [17]. First, the floating sections were incubated for 4 days at $4{ }^{\circ} \mathrm{C}$ with the primary Fos antibody (Ab-2, Oncogene Science, Cambridge, MA, USA, diluted 1:500). Then, the sections were further incubated for 2 hours with biotinylated secondary antibody solution (1:250), and finally with an avidin-biotin peroxidase complex (Vecta-stain ABC kit, Vector Laboratories Inc., Burlingame, CA, USA). The peroxidase in each section was visualized with $0.2 \%$ diaminobenzidine. The sections from both the control and the stress rats were processed simultaneously, to keep all conditions for the immunohistochemical procedures the same. The number of neurons containing Fos-like immunoreactivity (Fos-LI) was counted in the PVN using a light microscope. The results were presented as the mean number of Fos-LI neurons in 6 rats in each PVN.

\section{Endocrine examinations}

General index. Adrenal gland weight and thymus weight were measured with an Electronic Balance immediately after being removed from the body in all animals as the general indices of endocrine and immune system. Moreover, the occurrence of gastric ulcers was also investigated in all animals. The stomach was opened along the greater curvature, the lumen was washed with ice-cold saline, and the mucosa was examined macroscopically [18]. The ulcerative lesion with a diameter of more than $0.5 \mathrm{~mm}$ along its greatest diameter or three confluent petechiae were determined as a positive index of gastric ulcers.

Radioimmunoassay. Plasma samples were collected and stored at $-80^{\circ} \mathrm{C}$ until assay. To determine the plasma concentrations of ACTH and CORT, a radioimmunoassay was performed using a ${ }^{125} \mathrm{I}$-labled ACTH detection kit (Mitsubishi Kagaku Co., Tokyo, Japan) and a CORT detection kit (ICN Biomedicals Inc., Irvine, CA, USA). All plasma specimens for each assay were processed at the same time for the immunological measurements.

\section{Analysis of leukocyte subtypes}

Within 1 hour, the white blood cells (WBC) were counted, and the percentages of lymphocytes (LYM) and neutrophiles (NEU) were determined by a microscopic examination of peripheral blood smears stained conventionally. At least 200 cells were counted to produce each differential. The blood samples were used within 5 hours for flow cytometry (FCM) analyses. Specific subtypes of immune cells were measured by immunofluorescent antibody staining of whole blood and a subsequent analysis using Dual-color FCM (Cytoron Absolute, Ortho, Ralitan, NJ, USA). Briefly, $100 \mu \mathrm{l}$ of whole blood was incubated with 10 
$\mu \mathrm{l}$ of the appropriate monoclonal antibody for $30 \mathrm{~min}$ at $4{ }^{\circ} \mathrm{C}$. The red blood cells were lysed, and then an analysis of the samples was performed on the FCM after washing by phosphate buffered saline, PH 7.4 (PBS). For an analysis of the LYM subtypes, bit-map gating was initially set according to light scatter patterns and thereafter was subsequently adjusted to achieve at least $90 \%$ positive staining for the panel of antibody list below. The number of specific subtypes was derived from multiplying the WBC count by the LYM percentage and then by the specific subpopulation percentage. LYM subsets were defined using the following antibodies (PharMingen, San Diego, CA, USA): CD 5 and CD 8 were used as a marker for cytotoxic/suppressor T cells (CTL/Ts, CD 5 $/ \mathrm{CD}^{+}$) and NK cells (CD 5 $/ \mathrm{CD} 8^{+}$)

$[19,20]$. CD 4 was used as a marker for helper T cells $\left(\mathrm{Th}, \mathrm{CD} 4^{+}\right)$[21]. IgG 1 isotype controls were utilized to set the negative criterion for a histogram analysis.

\section{Statistics}

A computer statistics package was used for statistical analysis (Stat View J-5.0). The data were analyzed by two-way ANOVA followed by multiple comparisons using the Dunnett test. All data were expressed as the means \pm SEM and statistical significance was established at $P<0.05$.

\section{Results}

\section{General indices of RTS}

The general effects of RTS are shown in Table 1. BW decreased significantly at 16 hours

Table 1. General changes induced by continuous restraint stress

\begin{tabular}{lccccccc}
\hline & & 0 hour & 1 hour & 2 hours & 4 hours & 8 hours & 16 hours \\
\hline $\begin{array}{l}\text { Body weight } \\
\text { (BW, g) }\end{array}$ & Control & $310.3 \pm 6.1$ & $309.3 \pm 6.6$ & $311.2 \pm 7.6$ & $311.0 \pm 3.4$ & $308.7 \pm 3.4$ & $306.7 \pm 7.3$ \\
& Stress & $306.8 \pm 7.4$ & $306.2 \pm 5.7$ & $309.3 \pm 6.4$ & $300.5 \pm 7.7$ & $301.5 \pm 9.1$ & $270.8 \pm 6.0^{*}$ \\
& Control & $154.4 \pm 5.4$ & $153.8 \pm 5.3$ & $154.0 \pm 4.8$ & $152.9 \pm 5.3$ & $147.4 \pm 4.0$ & $147.6 \pm 5.4$ \\
$\begin{array}{l}\text { Thymus weight } \\
\text { (mg/100g BW) }\end{array}$ & Stress & $156.7 \pm 5.7$ & $155.6 \pm 5.8$ & $155.2 \pm 6.2$ & $158.0 \pm 7.6$ & $154.7 \pm 8.7$ & $155.6 \pm 5.6$ \\
& Control & $16.2 \pm 1.2$ & $16.2 \pm 1.2$ & $16.0 \pm 0.7$ & $16.0 \pm 0.8$ & $16.3 \pm 0.7$ & $16.2 \pm 1.1$ \\
$\begin{array}{l}\text { Adrenal gland weight } \\
\text { (mg/100g BW) }\end{array}$ & Stress & $15.9 \pm 0.6$ & $16.0 \pm 0.7$ & $16.2 \pm 1.2$ & $18.1 \pm 0.4$ & $18.4 \pm 1.0$ & $23.6 \pm 0.8 *$ \\
& Control & 0 & 0 & 0 & 0 & 0 & 0 \\
$\begin{array}{l}\text { Gastric lesions } \\
\text { (number of rats) }\end{array}$ & Stress & 0 & 0 & 0 & 0 & 1 & 6 \\
\hline
\end{tabular}

Means \pm SEM. $\mathrm{n}=6 .{ }^{*} P<0.05$ vs. baseline ( 0 hour) 
A

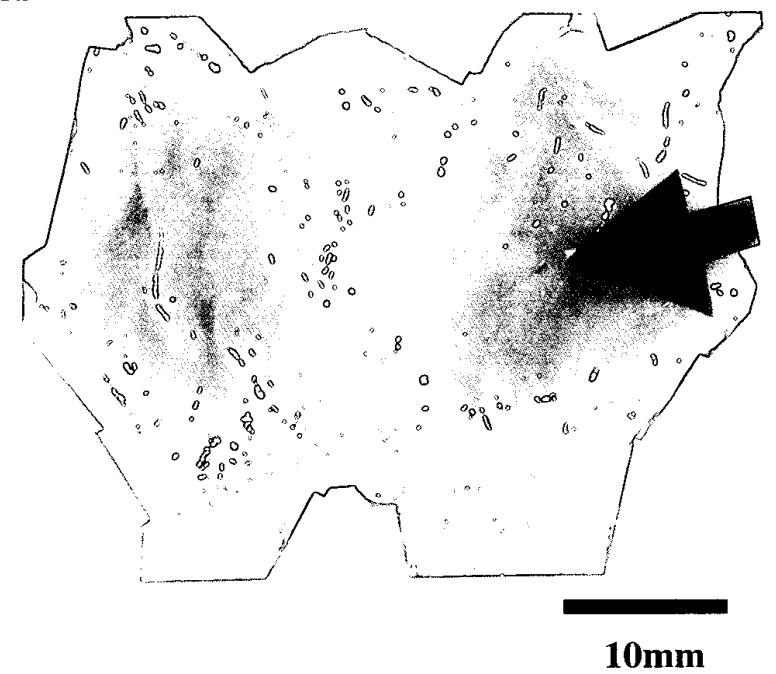

B

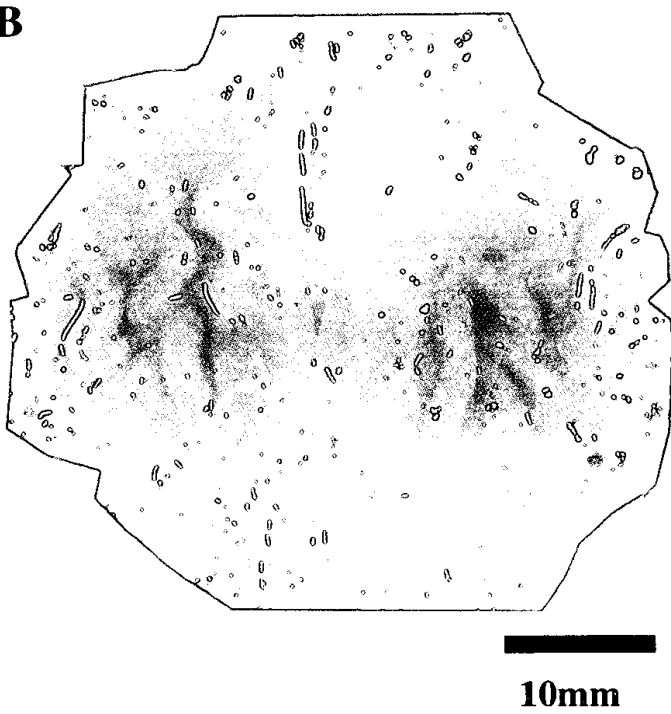

Fig. 2. Gastric mucosa in one of 16-hour stressed rats with ulcers over the mucosa following the congestion and edematous (A). Gastric mucosa in one of the 16-hour control rats with neither ulcer nor congestion or edematous (B).

of prolonged RTS $(P<0.05)$. The adrenal gland weight was significantly increased after 16 hours RTS $(P<0.001)$, whereas the thymus weight was significantly unchanged $(P>0.05)$ during the stress procedure. A gastric ulcer was found in $1 / 6$ at 8 hours and $6 / 6$ at 16 hours RTS (Fig. 2), respectively. However, no marked gastric erosions were observed in the untreated rats (0 hour) or rats with fasting only.

\section{RTS-induced c-fos expression}

The intensity and the time course of the c-fos mRNA signals in the PVN are shown in Fig. $3 \mathrm{~A}$. Little expression of $c$-fos mRNA was observed in the untreated animals ( 0 hour), however, in contrast, the hybridization signals for $c$-fos mRNA in the rats with stress were markedly increased $(P<0.0001)$. The measurements of autoradiograph density, expressed as a percentage of the baseline level ( 0 hour), were found to be maximal at 0.5 hour $(P<0.05)$ (Fig. $4 \mathrm{~A}$ and $4 \mathrm{~B})$, but were scarcely observed at 2 hours $(P>0.05)$, and then disappeared after 4 hours even under continuous stress.

The changes and the time course of Fos appearance in the PVN regions in each group are shown in Fig. $3 \mathrm{~B}$. A greater increase of Fos expression was detected after RTS $(P<0.0001)$. The number of Fos-LI neurous per hemisection was either absent or barely present at 0 hour, but increased significantly $(P<0.05)$ at 1 hour after the induction of the stress, reached its peak $(P<0.05)$ at 4 hours (Fig. $4 \mathrm{C}$ and $4 \mathrm{D}$ ), and continued to increase continuously at 8 hours $(P<0.05)$, but then gradually returned to the baseline levels ( 0 hour, 
$P>0.05)$ at 16 hours.

\section{Plasma hormone levels}

The activation of the HPA axis during RTS resulted in rapid increases in the plasma levels of ACTH $(P<0.01)$ (Fig. 5 A) and CORT $(P<0.0001)$ (Fig. 5 B). Whereas the increase
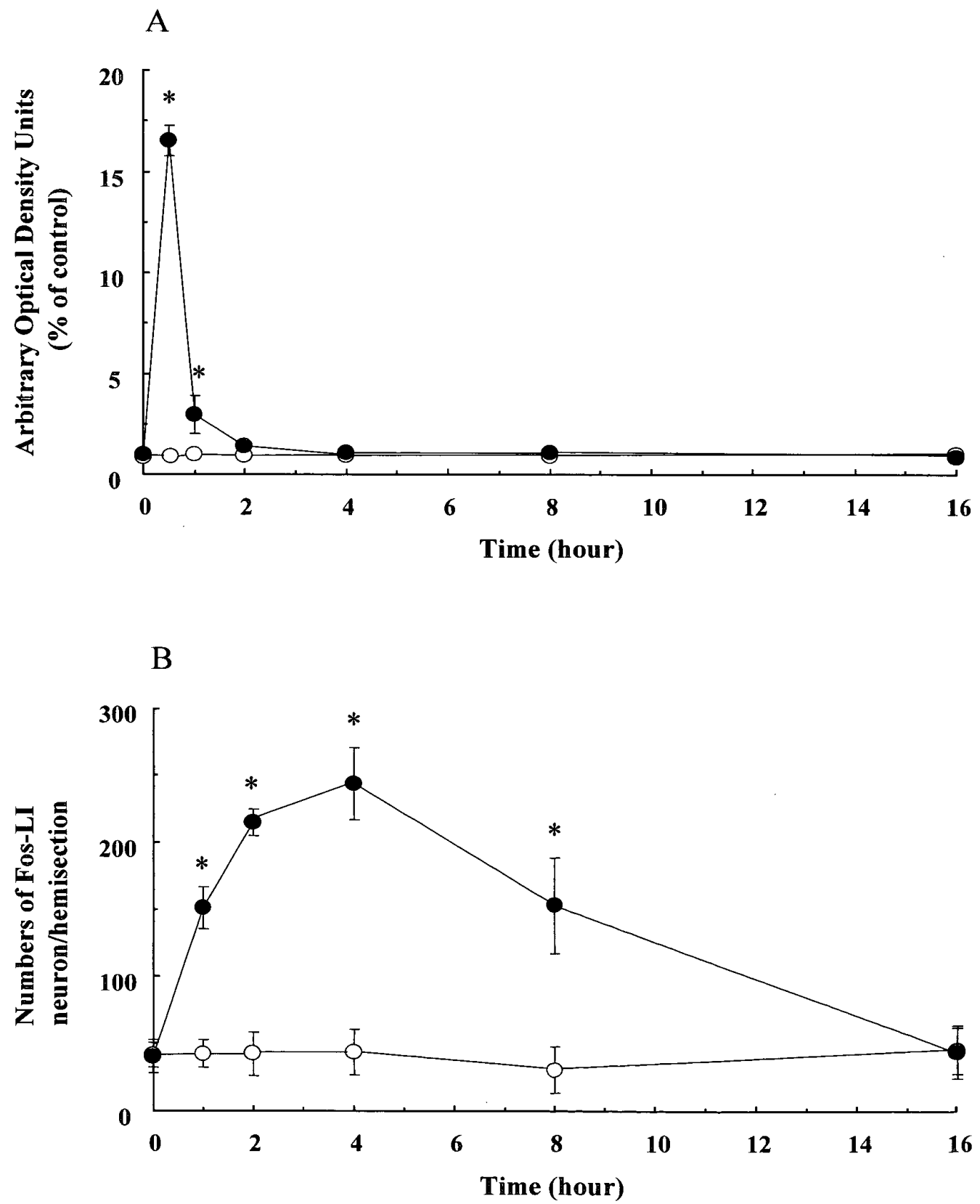

Fig. 3. The expression of $c$-fos mRNA in PVN $(\mathrm{A}, \mathrm{n}=3)$ and the numbers of Fos-LI neuron in PVN $(\mathrm{B}, \mathrm{n}=6)$ during 16-hour restraint stress sessions. The data are expressed as the means \pm SEM. Stressed rats $(\mathbf{O})$, Control rats $(\bigcirc) .{ }^{*} P<0.05$, significantly different from the baseline level $(0$ hour $)$. 

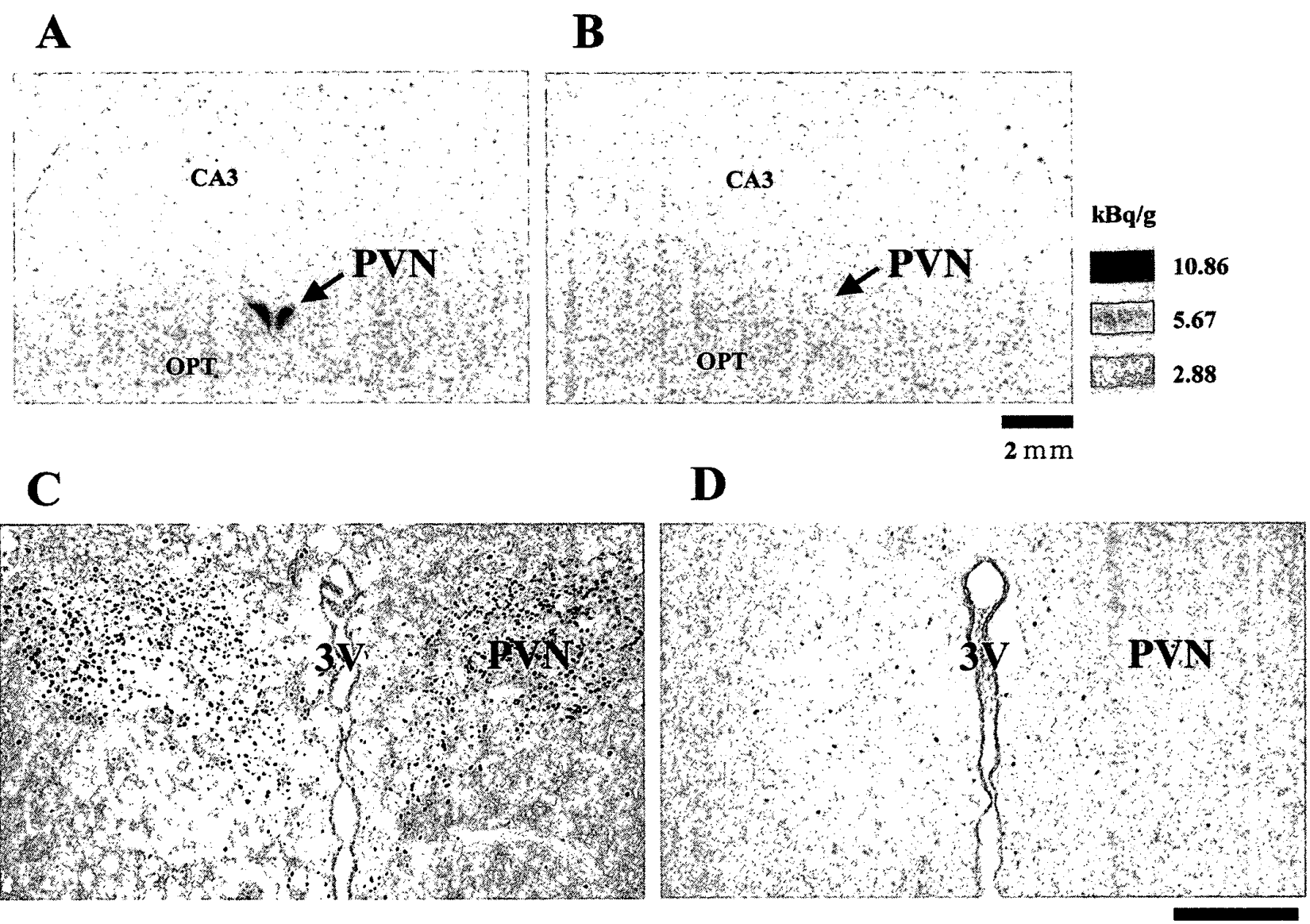

$220 \mu \mathrm{m}$

Fig. 4. Representative autoradiographs of sections hybridized by a ${ }^{35} \mathrm{~S}$-labeled probe to the $c$-fos mRNA in the PVN 0.5-hour stressed group (A) and control group (B). The density of autoradiographs was measured by comparing it with simultaneously exposed ${ }^{14} \mathrm{C}$-labeled microscale samples $(\mathrm{kBq} / \mathrm{g})$. Photomicrographs showing changes in Fos-LI in the PVN in 4-hour stressed group (C) and control group (D). The frontal sections at the level of PVN were used for the experiment. CA3: Ammon's horn. OPT: optic tract. 3V: third ventricle. PVN: paraventricular nucleus hypothalamus.

in ACTH was transient, the rise in CORT was maintained for the duration of the stress. The plasma ACTH levels reached a peak at 1 hour $(P<0.05)$, rapidly decreased at 2 hours $(P<0.05)$, and then gradually returned to the basal levels at 4,8 and 16 hours $(P>0.05)$. The concentration of CORT also reached a peak at 1 hour $(P<0.05)$, however, it decreased slightly at 2 hours $(P<0.05)$, and remained at a significantly higher level until the end of the stress protocol $(P<0.05$ at 4,8 and 16 hours $)$.

\section{Changes in distribution of peripheral blood leukocytes}

The number of WBC and blood leukocyte subtypes in the peripheral blood was measured 
during the stress session. As shown in Fig. 6 , a rapid significant decrease and then a slow recovery were observed in the number of $\operatorname{WBC}(P<0.0001)($ Fig. $6 \mathrm{~A})$ and $\operatorname{LYM}(P<0.0001)$ (Fig. 6 B) which reached their peaks at 2 hours $(P<0.05)$ after the induction of stress. The WBC number returned to the baseline level at 16 hours $(P>0.05)$, however, the LYM number did not return to the baseline level at the end of the stress (at 16 hours, $P<0.05$ ). An

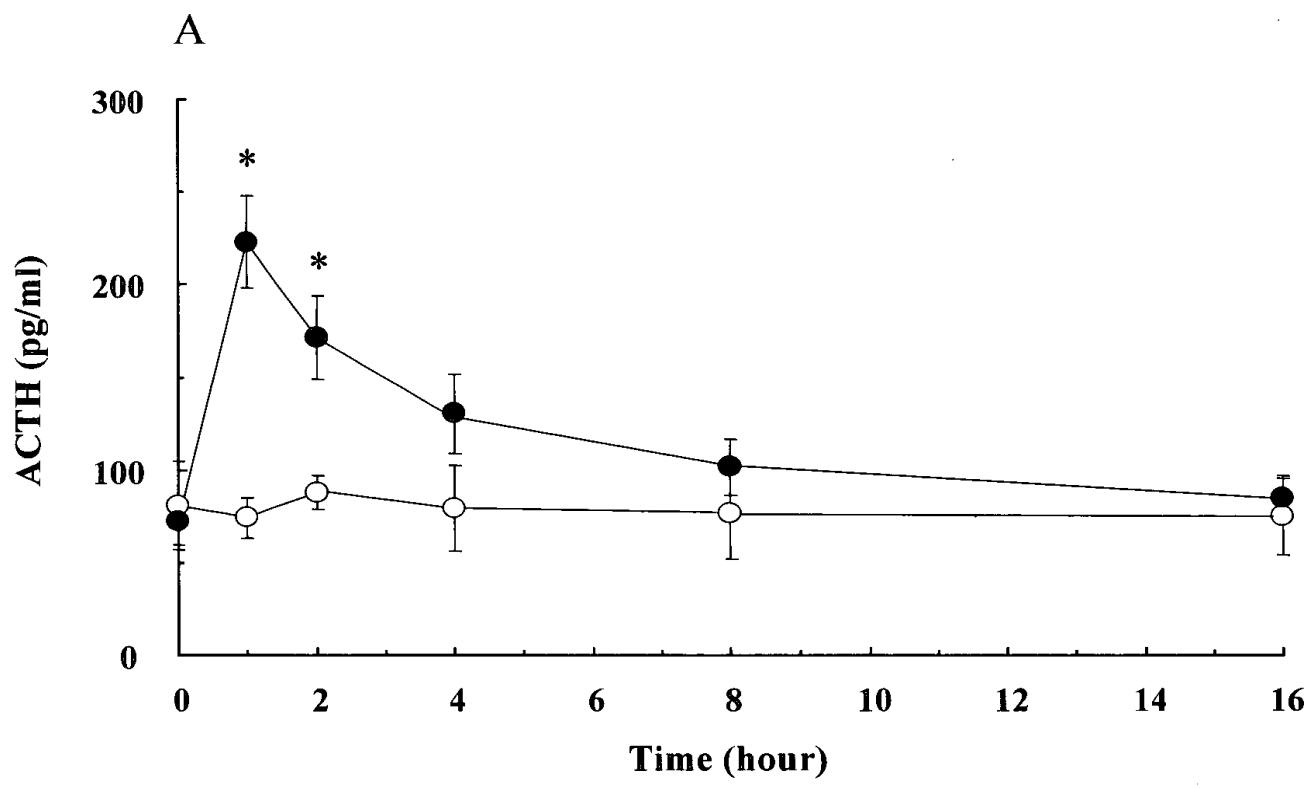

B

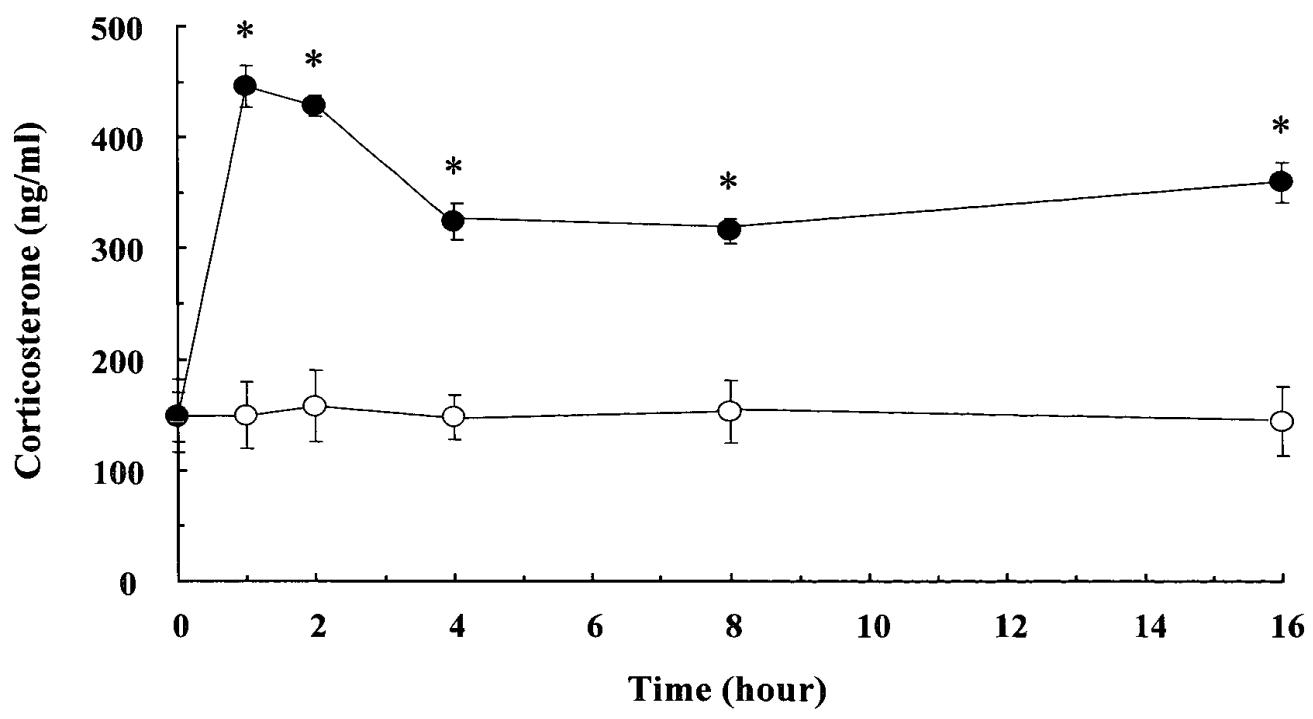

Fig. 5. Restraint stress-induced responses in the plasma hormone level. The changes in the plasma concentration of ACTH (A) and CORT (B) during 16-hour stress sessions are shown. The data are expressed as means \pm SEM. Stressed rats $(\bigcirc ; n=6)$, Control rats $(\bigcirc ; n=6) . \quad{ }^{*} P<0.05$, significantly different from the baseline level ( 0 hour). 

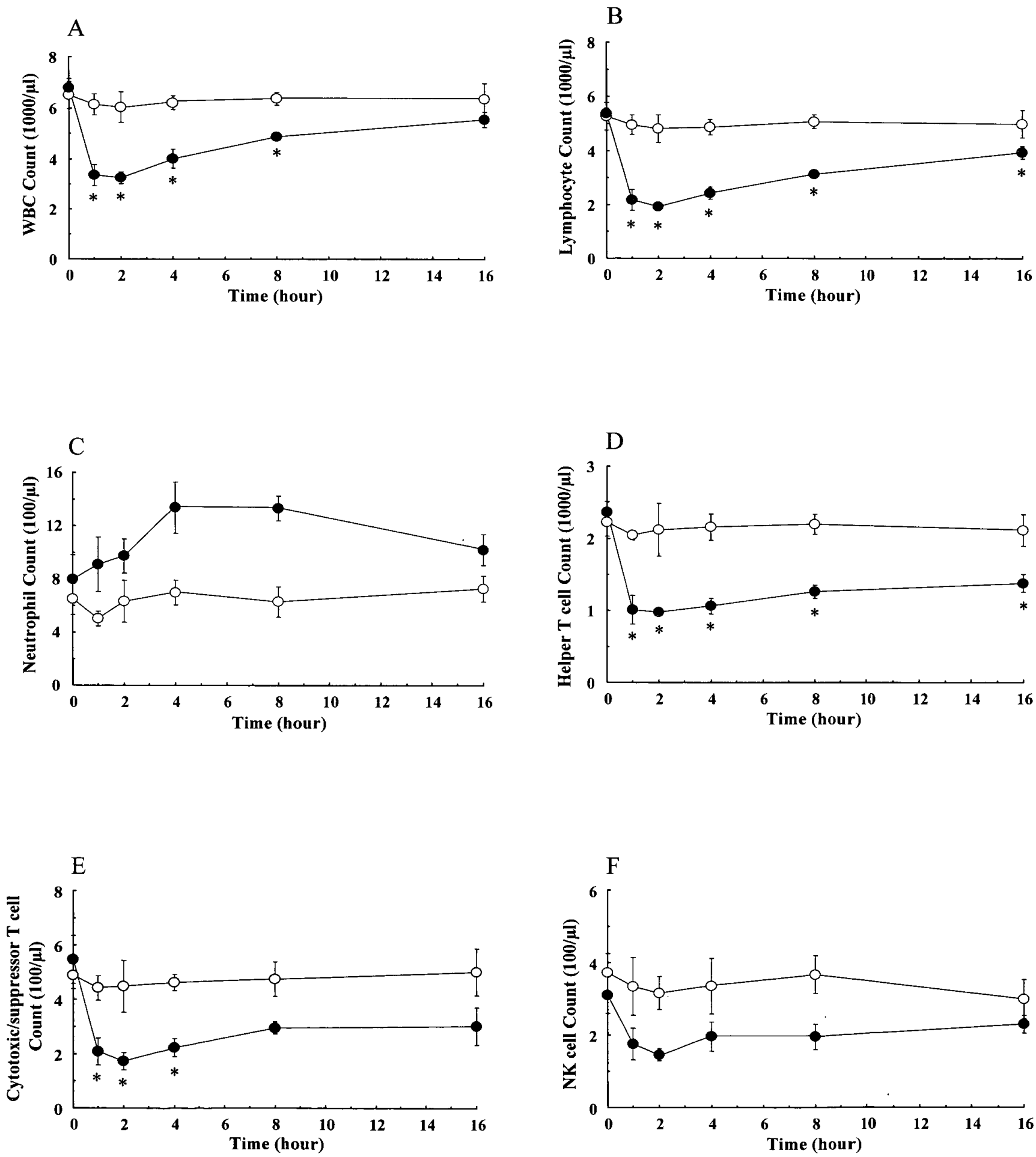

Fig. 6. Restraint stress-induced changes in the number of WBC (A), neutrophil (B), lymphocyte (C), helper T cells (Th, D), cytotoxic/suppressor T cells (CTL/Ts, E) and NK cells (F) during 16-hour stress sessions. The data are expressed as the means \pm SEM. Stressed rats $(\boldsymbol{n}=6)$, Control rats $(O ; \mathrm{n}=6) . \quad{ }^{*} P<0.05$, significantly different from the baseline level ( 0 hour). 
increase of the NEU number was observed, although it was not significant $(P<0.05)$ (Fig. $6 \mathrm{C}$ ) during the RTS session. Regarding the number of LYM subtypes, a similar change in the $\mathrm{Th}(P<0.001)$ (Fig. $6 \mathrm{D})$ and the CTL/Ts $(P<0.05)$ (Fig. $6 \mathrm{E}$ ) was detected, whereas no significant change in the NK cells $(P>0.05)$ (Fig. $6 \mathrm{~F}$ ) was found. Furthermore, the changes in the relative percentages of blood leukocyte subtypes during a 16-hour RTS session was almost the same as those regarding the number of blood leukocyte subtypes (data not shown).

\section{Discussion}

The expression of $c$-fos gene, as immediate early genes (IEGs), is rapidly and trainsiently induced by a diverse set of stimuli in many brain regions, and can thus serve as markers for neurocellular activity $[1,5]$. Many researchers have linked the $c$-fos gene expression in the PVN and HPA axis activity to CRH and AVP secretions in the PVN, because dual immunostaining has revealed that the nuclear Fos-LI existed in either CRH-LI containing neurons or AVP-LI containing cells in the PVN [22-24], and numerous studies have shown that acute stress-induced expression of the $C R H$ and $A V P$ genes in CRH-and AVPcontaining neurons in the PVN are later than the expression of IEGs such as $c$-fos mRNA [1, 7]. In accordance with other studies $[1,25]$, the present study revealed that neurons located in the PVN expressed the c-fos mRNA rapidly and temporally in the rats with RTS (peak at 0.5 hour and markedly diminished at 2 hours). In spite of the fact that stress continued, no further expression of $c$-fos mRNA was found at 4,8 and 16 hours. Adaptive changes in $c$-fos expression following repeated stress have been documented in several stressrelated brain regions. Chowdhury et al. [6] thought that adaptive changes in Fos expression to stress could also occur in acute stress conditions, where stress continues for an extended period of time. Thus, the present result is thought to be an adaptive phenomenon of the $c$-fos expression.

Fos, which is the corresponding protein product of $c$-fos, has also been proven to be a distinct marker for neural activation, and its expression has been demonstrated in response to a wide variety of experimental procedures [26-29]. Chowdhury et al. [6] showed that Fos expression reached its peak at 4 hours, and was persistently observed even at 8 hours in the PVN. In our present study the same results were confirmed, moreover, a disappearance of Fos expression at 16 hours was further shown. This phenomenon, the long-duration RTSinduced adaptive change in Fos expression in the PVN, was not observed by Chowdhury et al. [6]. These findings support the view that Fos expression is not only a distinct marker of neurocellular activity, but is also more useful in a long-duration RTS than $c$-fos mRNA [ 30 , 31]. In the present experiments, we showed that long-duration RTS induced clear changes in the induction and adaptation of both $c$-fos mRNA and Fos in the PVN. Moreover, it is noteworthy that there was a difference in time of adaptive changes between $c$-fos mRNA (peak at 0.5 hour, disappear at 2 hours) and Fos expression (peak at 4 hours, disappear at 16 
hours), which may be explained by the delay between gene expression and the production of protein $[32,33]$. The difference in stability of the mRNA and protein may also be a possibility.

The ability to cope with stress in mammals is known to involve the activation of the HPA axis that may be a final common pathway of the stress response [5]. As a result, the HPA axis is critical to an animal's response to stress [34]. In this study, a biphasic ACTH response to RTS, with a rapid and marked increase in the plasma ACTH level followed by a decline toward normal values despite the continuous presence of the stress, was observed.

In contrast to the ACTH, the plasma CORT level, a major component of glucocorticoid, was significantly elevated throughout the RTS duration. The fact that there was a correlation between the ACTH and CORT levels during short-duration stress, but a dissociation during long-duration stress, especially the latter, is considered to be an important phenomenon for the adaptation to continuous stress and preparation for novel stress. This finding is consistent with the report of a discrepancy between the ACTH and CORT levels in prolonged IMOS [35], which is severer stress than RTS [6]. Short-duration RTS stimulates the release of CRH and AVP from the PVN, thus inducing the secretion of ACTH from the pituitary, and the consequent ACTH-induced secretion of CORT from the adrenal cortex [2 $-4,8]$, causing the CORT levels to be closely correlated with the ACTH. On the other hand, the glucocorticoid and $\mathrm{CRH}$, that play a regulatory role in the basal activity of the HPA axis, can inhibit ACTH secretion either directly at the pituitary and hypothalamic levels or indirectly [36-38] during prolonged stress. Hauger et al. [35] indicated that the decrease in plasma ACTH during the adaptation phase to stress was accompanied by decreases in the pituitary CRH receptors, and not by those in the other brain areas CRH receptors. The mechanism of the persistent higher CORT level during long-duration RTS has not been clearly explained up to now. Our findings are consistent with a report that the CORT secretion rate is maximal with plasma ACTH levels in the lower third of the physical range, which indicates the possibility that during prolonged stress the adrenal is sensitized to small increases in ACTH. A decrease in the CORT clearance in the liver may partially contribute to the elevated plasma CORT level [39]. Another possibility is that under conditions of continuous stress, the adrenal cortex undergoes an adaptation, an increase in ACTH receptor activity induced by an increase in their number in the adrenal gland cortex, which thus allows the hypersecretion of glucocorticoids to occur even without an increase in ACTH [2].

It has been demonstrated that stress-induced changes in the cellular immunity are more susceptible than the humoral response [40]. In addition, the number and proportions of leukocytes in the blood provide an important representation of the state of distribution of leukocytes in the body and of the state of activation of the immune system [4]. As a result, these findings may serve as an index to measure the changes in the immune function. The present study showed changes with a complete recovery in the numbers of total WBC and CTL/Ts cells, changes with a partial recovery in the numbers of LYM and Th cells, and no 
significant changes in the number of NEU cells and NK cells, though an increased tendency in NEU cells and a decreased tendency in NK cells were observed during the 16 hours RTS session.

In this study, the short-duration acute RTS-induced changes in the blood leukocytes corresponding to an increase in the plasma CORT, are consistent with the concept initiated by Dhabhar et al . : stress-induced changes in leukocyte distribution are due to a redistribution of leukocytes from the blood to other organs in the body, which are mainly mediated by CORT acting at the Type II adrenal steroid receptor $[4,10,39,41]$. The changes in the blood leukocyte subpopulation are mediated by stress-induced changes in either the expression or affinity of surface adhesion molecules on leukocytes and/or endothelial cells [42]. As a result, each change is different among the leukocyte subtypes in the blood $[10,39]$. Prolonged stress-induced changes were characterized by a complete recovery in CTL/Ts cells at 8 hours and in the total WBC at 16 hours, a partial recovery (a gradual but no complete recovery, and still a significant decrease) in LYM and Th cells at 16 hours, and a slight increase and decrease but no significant changes in the NEU and NK cells, respectively. The magnitude and time-course of these changes were different for each subpopulation of leukocytes. Although these changes may be due to the adaptation, the detailed mechanisms of these recoveries in the number of blood leukocyte subtypes during prolonged RTS have yet to be elucidated. Evidently, in contrast to the continuous higher level of plasma CORT, the recovery changes of the blood leukocyte subtypes could not be explained by the mechanism of short-duration acute stress-induced changes. Various animal experiments have indicated that the distribution of an absolute number of specific blood leukocyte subtypes may be affected by the ambient concentrations of epinephrine, norepinephrine and CORT, and also by the densities of $\alpha, \beta$ adrenergic and Type II adrenal steroid receptors on the surface numbers of each leukocyte subpopulation. The differences in the concentrations and combinations of these hormones may explain the different consequences in the blood leukocyte numbers between long-duration and short-duration acute stress [4]. Moreover, apoptotic death of lymphocytes is also thought to be one of the reasons for leukocyte reduction in the peripheral blood during continuous RTS $[11,43]$. Apoptosis could be induced by glucocorticoids under certain conditions [44]. The involvement of a further mechanism was suggested by Yin et al. [45] who demonstrated that stress modulated the immune system through CD95-mediated apoptosis dependent on endogenous opioids. The number of total WBC increased more at 16 hours than at 8 hours in the present study, which is a little different from the results of Shimizu et al. [11] in which the number of total WBC in the blood decreased more at 24 hours than at 12 hours. This may be due to the apoptosisinduced re-decrease in the number of blood leukocyte subtypes, although this phenomenon could not be observed in our study, which was terminated at 16 hours.

Many studies have described that certain stress can induce BW reduction, thymus shrinkage and adrenal gland hypertrophy $[35,40,46-51]$. And it has been known that the 
magnitude of these changes is closely related to the nature and duration of stress. In the present study, the BW, weights of the thymus and adrenal gland were also measured as general indices of the stress response. During 9 session of RTS, as a result of increase in the animal's fecal excretion and the congestion of the adrenal gland, the result showed that there was a significant decrease in the $\mathrm{BW}$, whereas there was a significant increase in the weight of the adrenal gland during the 16-hour RTS session. Meanwhile, no significant change in the weight of the thymus was observed. The 16-hour RTS used in the present study may be too short to induce thymus shrinkage, which usually occurrs under continuous stress for more than 48 hours [35].

The present study indicated that at least one or more gastric lesions and ulcers were found in all of the animals $(6 / 6)$ with RTS at 16 hours and $1 / 6$ at 8 hours. However, no marked gastric erosions were observed before 8 hours RTS, or in any of the fasting or untreated rats.

The induction of mucosal injury in the stomach by RTS seems to take a longer time compared to that of other stress markers such as $c$-fos expression in the PVN, activation of HPA axis and changes of lymphocyte subpopulation. In addition to the involvement of the CNS components, such as the hypothalamus etc., gastric barrier mucus reduction, mucosal ischemia and enhanced back-diffusion of hydrogen ions have been proposed to be major local mechanisms for these stress-induced injuries [52-54].

In conclusion, the present study provides the characteristic features of the stress response induced by a single continuous RTS model, which thus indicates that the magnitude and time course of the stress response may be different in the PVN in the hypothalamus, pituitary, adrenal gland, immune system and stomach mucous membrane. The stress response during a single continuous RTS seems to consist of 2 stages. The first is the early stage in which acute stress reactions may be immediately evoked after stress exposure in the CNS, HPA axis and other systems and organs. The second is the late stage in which adaptation may occur in the CNS, HPA axis and the immune system following an acute stress response in the early stage with damage being observed in some organs, such as the stomach at this stage.

This study was supported by a Grant-in-Aid for Scientific Research from the Ministry of Education, Science, Sports and Culture of Japan (13670076).

\section{References}

1. Senba E \& Ueyama T (1997): Stress-induced expression of immediate early genes in the brain and peripheral organs of the rat. Neurosci Res 29: 183-207

2. Pignatelli D, Magalhaes MM \& Magalhaes MC (1998): Direct effects of stress on adrenocortical function. Horm Metab Res 30: 464-474

3. Nagata S (1993): Stress-induced immune changes, and brain-immune interaction. J UOEH 15: $161-171$ (in Japanese) 
4. Dhabhar FS (2000): Acute stress enhances while chronic stress suppresses skin immunity. The role of stress hormones and leukocyte trafficking. Ann N Y Acad Sci 917: 876-893

5. Cullinan WE, Herman JP, Battaglia DF, Akil H \& Watson SJ (1995): Pattern and time course of immediate early gene expression in rat brain following acute stress. Neuroscience 64: 477-505

6. Chowdhury GM, Fujioka T \& Nakamura S (2000): Induction and adaptation of Fos expression in the rat brain by two types of acute restraint stress. Brain Res Bull 52: $171-182$

7 . Imaki T, Shibasaki T \& Demura H (1995): Regulation of gene expression in the central nervous system by stress: molecular pathways of stress responses. Endocr J 42: 121-130

8. Assenmacher I, Barbanel G, Gaillet S, Givalois L, Ixart G, Malaval F, Mekaouche M, Siaud P \& Szafarczyk A (1995): Central regulation of ACTH release in stress. Ann N Y Acad Sci 771: 41-54

9. Lawrence DA \& Kim D (2000): Central/peripheral nervous system and immune responses. Toxicology 142: $189-201$

10. Dhabhar FS, Miller AH, McEwen BS \& Spencer RL (1995): Effects of stress on immune cell distribution. Dynamics and hormonal mechanisms. J Immunol 154: 5511-5527

11. Shimizu T, Kawamura T, Miyaji C et al (2000): Resistance of extrathymic T cells to stress and the role of endogenous glucocorticoids in stress associated immuno suppression. Scand J Immunol 51: $285-292$

12. Moroda T, Iiai T, Tsukahara A, Fukuda M, Suzuki S, Tada T, Hatakeyama K \& Abo T(1997): Association of granulocytes with ulcer formation in the stomach of rodents exposed to restraint stress. Biomed Res 18: 423-437

13. Glavin GB, Pare WP, Sandbak T, Bakke HK \& Murison R (1994): Restraint stress in biomedical research: an update. Neurosci Biobehav Rev Summer 18: 223-249

14. Harbuz MS, Chalmers J, De Souza L \& Lightman SL (1993): Stress-induced activation of CRF and $c$-fos mRNA in the paraventricular nucleus are not affected by serotonin depletion. Brain Res 609: $167-173$

15. Serino R, Ueta Y, Hara Y et al (1999): Centrally administered adrenomedullin increases plasma oxytocin level with induction of $c$-fos messenger ribonucleic acid in the paraventricular and supraoptic nuclei of the rat. Endocrinol 140: 2334-2342

16. Swanson LW (1992): Brain maps: structure of the rat brain. Elsevier, Amsterdam pp 25-27

17. Ueta Y, Yamashita H, Kawata M \& Koizumi K (1995): Water deprivation induces regional expression of $c$-fos protein in the brain of inbred polydipsic mice. Brain Res 677: 221-228

18. Yelken B, Dorman T, Erkasap S, Dundar E \& Tanriverdi B (1999): Clonidine pretreatment inhibits stress-induced gastric ulcer in rats. Anesth Analg 89: 159-162

19. Barclay AN (1981): The localization of populations of lymphocytes defined by monoclonal antibodies in rat lymphoid tissues. Immunol 42: 593-600

20. Johnson P, Gagnon J, Barclay AN \& Williams AF (1985): Purification, chain separation and sequence of the MRC OX-8 antigen, a marker of rat cytotoxic T lymphocytes. EMBO J 4: $2539-2545$

21. Jefferies WA, Green JR \& Williams AF (1985): Authentic T helper CD 4（W3/25） antigen on rat 
peritoneal macrophages. J Exp Med 162: 117-127

22. Rivest S, Torres G \& Rivier C (1992): Differential effects of central and peripheral injection of interleukin-1 beta on brain $c$-fos expression and neuroendocrine functions. Brain Res 587: 13-23

23. Veening JG, van der Meer MJ, Joosten H, Hermus AR, Rijnnkels CE, Geeraedts LM \& Sweep CG (1993): Intravenous administration of interleukin-1 beta induces Fos-like immunoreactivity in corticotropin-releasing hormone neurons in the paraventricular hypothalamic nucleus of the rat.

J Chem Neuroanat 6: $391-397$

24. Nomura M, Ueta Y, Serino R, Yamamoto Y, Shibuya I \& Yamashita H (1999): Effects of centrally administered pituitary adenylate cyclase-activating polypeptide on $c$-fos gene expression and heteronuclear RNA for vasopressin in rat paraventricular and supraoptic nuclei. Neuroendocrinology 69: $167-180$

25. Umemoto S, Kawai Y, Ueyama T \& Senba E (1997): Chronic glucocorticoid administration as well as repeated stress affects the subsequent acute immobilization stress-induced expression of immediate early genes but not that of NGFI-A. Neurosci $\quad 80: 763-773$

26. Li C, Chen P \& Smith MS (1999): Neural populations in the rat forebrain and brainstem activated by the suckling stimulus as demonstrated by cFos expression. Neuroscience $94: 117-129$

27. Yokoyama C \& Sasaki K (1999): Regional expressions of Fos-like immunoreactivity in rat cerebral cortex after stress: restraint and intraperitoneal lipopolysaccharide. Brain Res 816: 267-275

28. Miyata S, Nakashima T \& Kiyohara T (1994): Expression of $c$-fos immunoreactivity in the hypothalamic magnocellular neurons during chronic osmotic stimulations. Neurosci Letters 175: 63-66

29. Baffi JS \& Palkovits M (2000): Fine topography of brain areas activated by cold stress. A fos immunohistochemical study in rats. Neuroendocrinology 72: 102-113

30. Ceccatelli S, Villar MJ, Goldstein M \& Hokfelt T (1989): Expression of $c$-fos immunoreactivity in transmitter-characterized neurons after stress. Proc Natl Acad Sci USA 86: 9569-9573

31. Kononen J, Honkaniemi J, Alho H, Koistinaho J, Iadarola M \& Pelto-Huikko M (1992): Fos-like immunoreactivity in the rat hypothalamic-pituitary axis after immobilization stress. Endocrinol 130: $3041-3047$

32. Winston SM, Hayward MD, Nestler EJ \& Duman RS (1990): Chronic electroconvulsive seizures down-regulate expression of the immediate-early genes $c$-fos and $c$-jun in rat cerebral cortex. J Neurochem 54: 1920-1925

33. Senba E, Matsunaga K, Tohyama M \& Noguchi K (1993): Stress-induced $c$-fos expression in the rat brain: activation mechanism of sympathetic pathway. Brain Res Bull 31: 329--344

34. Day HE, Campeau S, Watson SJ Jr \& Akil H (1999): Expression of alpha (1b) adrenoceptor mRNA in corticotropin-releasing hormone-containing cells of the rat hypothalamus and its regulation by corticosterone. J Neurosci 19: 10098-10106

35. Hauger RL, Millan MA, Lorang M, Harwood JP \& Aguilera G (1988): Corticotropin-releasing factor receptors and pituitary adrenal responses during immobilization stress. Endocrinol 123: $396-405$

36. Rivier C \& Vale W (1987): Diminished responsiveness of the hypothalamic-pituitary-adrenal axis 
of the rat during exposure to prolonged stress: a pituitary-mediated mechanism. Endocrinol 121: $1320-1328$

37. Dallman MF, Akana SF, Jacobson L, Levin N, Cascio CS \& Shinsako J (1987): Characterization of corticosterone feedback regulation of ACTH secretion. Ann N Y Acad Sci 512: 402-414

38. Dallman MF, Akana SF, Cascio CS, Darlington DN, Jacobson L \& Levin N (1987): Regulation of ACTH secretion: variations on a theme of B. Recent Prog Horm Res 43: 113-173

39. Aguilera G, Kiss A, Lu A \& Camacho C (1996): Regulation of adrenal steroidogenesis during chronic stress. Endocr Res 22: $433-443$

40. Millán S, González-Quijano MI, Giordano M, Soto L, Martin AI \& López-Calderón A (1996): Short and long restraint differentially affect humoral and cellular immune functions. Life Sci 59: $1431-1442$

41. Dhabhar FS, Miller AH, McEwen BS \& Spencer RL (1996): Stress-induced changes in blood leukocyte distribution. Role of adrenal steroid hormones. J Immunol 157: 1638-1644

42. Tarcic N, Levitan G, Ben-Yosef D, Prous D, Ovadia H \& Weiss DW (1995): Restraint stressinduced changes in lymphocyte subsets and the expression of adhesion molecules. Neuroimmunomodulation 2: $249-257$

43. Tarcic N, Ovadia H, Weiss DW \& Weidenfeld J (1998): Restraint stress-induced thymic involution and cell apoptosis are dependent on endogenous glucocorticoids. J Neuroimmunol 82: 40-46

44 . Cohen JJ (1992): Glucocorticoid-induced apoptosis in the thymus. Semin Immunol 4: 363-369

45. Yin D, Tuthill D, Mufson RA \& Shi Y (2000): Chronic restraint stress promotes lymphocyte apoptosis by modulating CD95 expression. J Exp Med 191: 1423-1428

46. Selye H (1936): A syndrome produced by diverse nocuous agents. Nature 138: $32-33$

47. Du Ruisseau P, Tache Y, Selye H, Ducharme JR \& Collu R (1977): Effects of chronic stress on pituitary hormone release induced by combined hemi-extirpation of the thyroid, adrenal and ovary in rats. Neuroendocrinology 24: $169-182$

48. Tache Y, Du Ruisseau P, Ducharme JR \& Collu R (1978): Pattern of adenohypophyseal hormone changes in male rats following chronic stress. Neuroendocrinology 26: 208-219

49. Haleem DJ, Kennett G \& Curzon G (1988): Adaptation of female rats to stress: shift to male pattern by inhibition of corticosterone synthesis. Brain Res 458: $339-347$

50. Marti O, Gavalda A, Jolin T \& Armario A (1993): Effect of regularity of exposure to chronic immobilization stress on the circadian pattern of pituitary adrenal hormones, growth hormone, and thyroid stimulating hormone in the adult male rat. Psychoneuroendocrinology 18: 67-77

51 . Marti O, Marti J \& Armario A (1994): Effects of chronic stress on food intake in rats: influence of stressor intensity and duration of daily exposure. Physiol Behav 55: 747-753

52. Glavin GB, Murison R, Overmier JB, Pare WP, Bakke HK, Henke PG \& Hernandez DE (1991): The neurobiology of stress ulcer. Brain Res Rev 16: 301-343

53. Martinez-Augustin O, Sanchez de Medina F Jr \& Sanchez de Medina F (2000): Effect of psychogenic stress on gastrointestinal function. J Physiol Biochem 56: 259-274

54. Yabana T \& Yachi A (1988): Stress-induced vascular damage and ulcer. Dig Dis Sci 33: 751-761 
拘束ストレス時の室傍核 $c-f o s$ 発現と HPA 系・免疫系の反応

譚正国, 永田 頌史

産業医科大学産業生態科学研究所 精神保健学教室

要旨： ストレスが中枢神経系，内分泌系，免疫系及び消化管のような末梢器官に影響を及 ほすことはよく知られている。しかし，ストレスが長時間続いた時のこれらの系や 器官に生じる急性ストレス反応後の適応あるいは回復のプロセスについては，充分 検討されていない。これらの系や器官の急性ストレス反応後の適応・回復過程を明 らかにするために，長時間拘束ストレス中のこれらの反応を経時的に調べた．その 結果，(1PVNのc-fos mRNA 発現は30分後にピークに達した，その 2 時間後には前 值（ベースライン值）に戾り，c-fos 蛋白は 4 時間後にピークに達した後, 16時間後 には前值に戻った. (2)ACTH は 1 時間後にピークに達した後， 8 時間後に前値に戻 った.コルチコステロンは 1 時間後にピークに達した後漸減したが, $4,8,16$ 時間 後でもな捛高值を示した. (3)血中白血球, リンパ球, helper $\mathrm{T}$ 細胞, cytotoxic/suppressor $\mathrm{T}$ 細胞計数は 2 時間後に最低值に達した後, 漸増した. (4)胃潰瘍の発生率は 8 時 間後に $1 / 6$ 匹，16時間後に 6/6匹であった。これらの結果から，長時間拘束時のス トレス反忘のピークや適応現象には器官によって差がみられることが示唆された。

J UOEH（産業医大誌）24（2）:131-149（2002） 